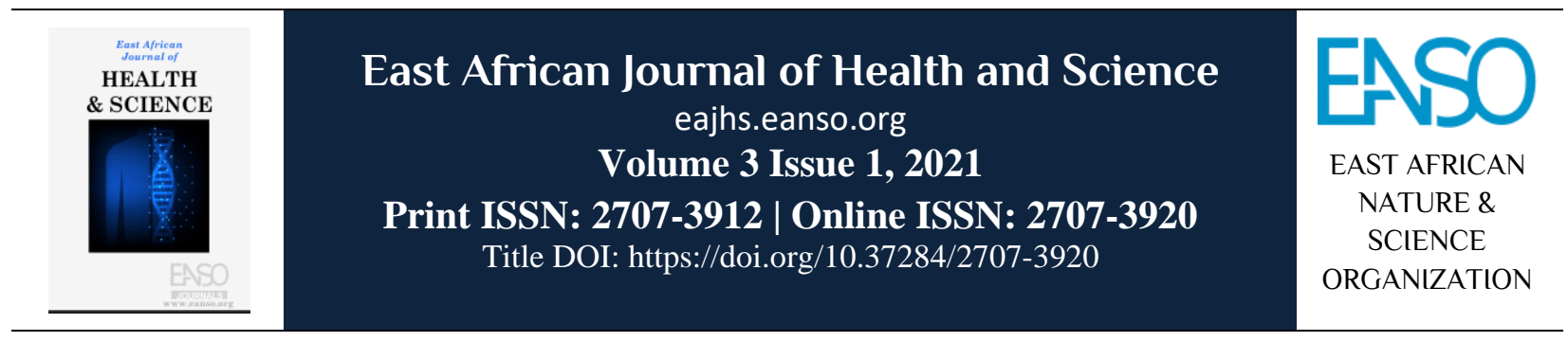

Original Article

\title{
Evaluation of Some Toxic Heavy Metals in Rice and Beans Samples Cultivated in Yobe State, Nigeria.
}

\author{
Dr. Muhammad Ibrahim Usman, PhD ${ }^{1}$, Dr. Madu Adamu Gadaka, hhD $^{1}$ \& Abubakar \\ Bilyamini Maazu ${ }^{l}$ \\ ${ }^{1}$ Department of Biochemistry, Faculty of Science, Yobe State University, Damaturu, Nigeria \\ *Author for correspondence email: ibrahimmuhd@yahoo.com.
}

Article DOI: https://doi.org/10.37284/eajhs.3.1.396

\section{Date Published: ABSTRACT}

28 August 2021 Grains have become an integral part of the human diet due to their nutritional values, thus any form of contamination especially by heavy

Keywords: metals is of great concern. This research evaluated the level of Cadmium, Chromium, Lead and Mercury in the commonly consumed foods (Rice and

Heavy Metals, Beans) across Yobe State, North-eastern Nigeria. A composite sample from

Toxicity, each of the three Senatorial Zones was collected from farm harvests and Rice, designed as ZAR, ZAB, ZBR, ZBB, ZCR and ZCB for Zone A Rice, Zone A Beans, Zone B Rice, Zone B Beans, Zone C Rice and Zone C Beans respectively. The metal Concentration was determined using atomic Yobe State, absorption spectroscopy (AAS). Results in $\mathrm{mg} / \mathrm{Kg}$ across the local Nigeria. governments indicates respective ranges for $\mathrm{Hg}, \mathrm{Pb}, \mathrm{Cd}$, and $\mathrm{Cr}$ of 0.30 4.04, $0.16-0.92,0.03-0.05$ and 0.02- 0.52 in Rice, 0.14-3.73, 0.05-0.33, 0.05-0.07 and 0.00-0.14 in beans. Comparison of the results showed that with the exception of mercury, all metals are within the tolerable ranges set by International Standard Tolerable Limits and European Regulatory Standard. Potential hazards may be speculated because the detected levels are on the higher side of the tolerable ranges. A higher level of mercury in samples collected from Zone $\mathrm{C}$ might be associated with the reported cases of chronic kidney diseases from those areas.

\section{APA CITATION}

Usman, M. I., Gadaka, M. A. \& Maazu, A. B. (2021). Evaluation of Some Toxic Heavy Metals in Rice and Beans Samples Cultivated in Yobe State, Nigeria. East African Journal of Health and Science, 3(1), 145-151. https://doi.org/10.37284/eajhs.3.1.396. 
East African Journal of Health and Science, Volume 3, Issue 1, 2021

Article DOI: https://doi.org/10.37284/eajhs.3.1.396

\section{CHICAGO CITATION}

Usman, Muhammad Ibrahim, Madu Adamu Gadaka, \& Abubakar Bilyamini Maazu. 2021. "Evaluation of Some Toxic Heavy Metals in Rice and Beans Samples Cultivated in Yobe State, Nigeria.". East African Journal of Health and Science 3 (1), 145151. https://doi.org/10.37284/eajhs.3.1.396.

\section{HARVARD CITATION}

Usman, M. I., Gadaka, M. A., and Maazu, A. B. (2021) "Evaluation of Some Toxic Heavy Metals in Rice and Beans Samples Cultivated in Yobe State, Nigeria.", East African Journal of Health and Science, 3(1), pp. 145-151. doi: 10.37284/eajhs.3.1.396.

\section{IEEE CITATION}

M. I. Usman, M. A. Gadaka, \& A. B. Maazu, "Evaluation of Some Toxic Heavy Metals in Rice and Beans Samples Cultivated in Yobe State, Nigeria.”, EAJHS, vol. 3, no. 1, pp. 145-151, Aug. 2021.

\section{MLA CITATION}

Usman, Muhammad Ibrahim, Madu Adamu Gadaka, \& Abubakar Bilyamini Maazu. "Evaluation of Some Toxic Heavy Metals in Rice and Beans Samples Cultivated in Yobe State, Nigeria.". East African Journal of Health and Science, Vol. 3, no. 1, Aug. 2021, pp. 145-151, doi:10.37284/eajhs.3.1.396.

\section{INTRODUCTION}

Lack of food safety is a major problem in most developing nations including Nigeria. Many of our food items are laden with lots of pollutants ranging from fertilizer, pesticides to heavy metals. Consumption of contaminated foods has serious implications on the health and economic status of the populace (WHO, 2020). Dietary exposure to heavy metals, namely Cadmium $(\mathrm{Cd})$, Lead $(\mathrm{Pb})$, Zinc ( $\mathrm{Zn})$, Arsenic (As) and Copper $(\mathrm{Cu})$ has been identified as a risk to human health through the consumption of contaminated food (Madyiwa, 2007). They occur as natural constituents of the earth crust and are also distributed by human activities. These heavy metals contaminate food sources and accumulate in both agricultural products and seafood through water, air and soil pollution. Most heavy metals are very harmful because of their non-biodegradable nature, long biological half-lives and their potential to accumulate in different body parts.

Consuming heavy metal-contaminated food can seriously deplete some essential nutrients in the body causing a decrease in immunological defences, intrauterine growth retardation, impaired psycho-social behaviour, disabilities associated with malnutrition and a high prevalence of upper gastrointestinal cancer (Gray, et al., 2003). It can also lead to other serious health complications such as kidney disease, damage to the nervous system, diminished intellectual capacity, heart disease, bone fractures and death (Carpenter, 2001).

\section{MATERIALS AND METHODS}

\section{Study area}

Yobe State formally came into being on August 27, 1991. It is situated in a semi-arid region located between latitudes $10.00^{\circ} \mathrm{N}$ to $11.30^{\circ} \mathrm{E}$ and longitude $12.00^{\circ} \mathrm{N}$ and $11.50^{\circ} \mathrm{E}$. Yobe State is at 472.45 meters above sea level and bordered by Bauchi, Borno, Gombe and Jigawa State. It has a total land area of 45,502 square kilometres with an estimated $1,754,200$ hectares agricultural and over 70,000 hectares of forest vegetation and grazing land. The state is noted for its fairly stable climate with relatively minor changes in temperature and humidity. Agriculture is the mainstay of the economy involving at least $75 \%$ of the rural population. Important crops produced in the State include maize, beans, rice, corn and varieties of vegetables. 


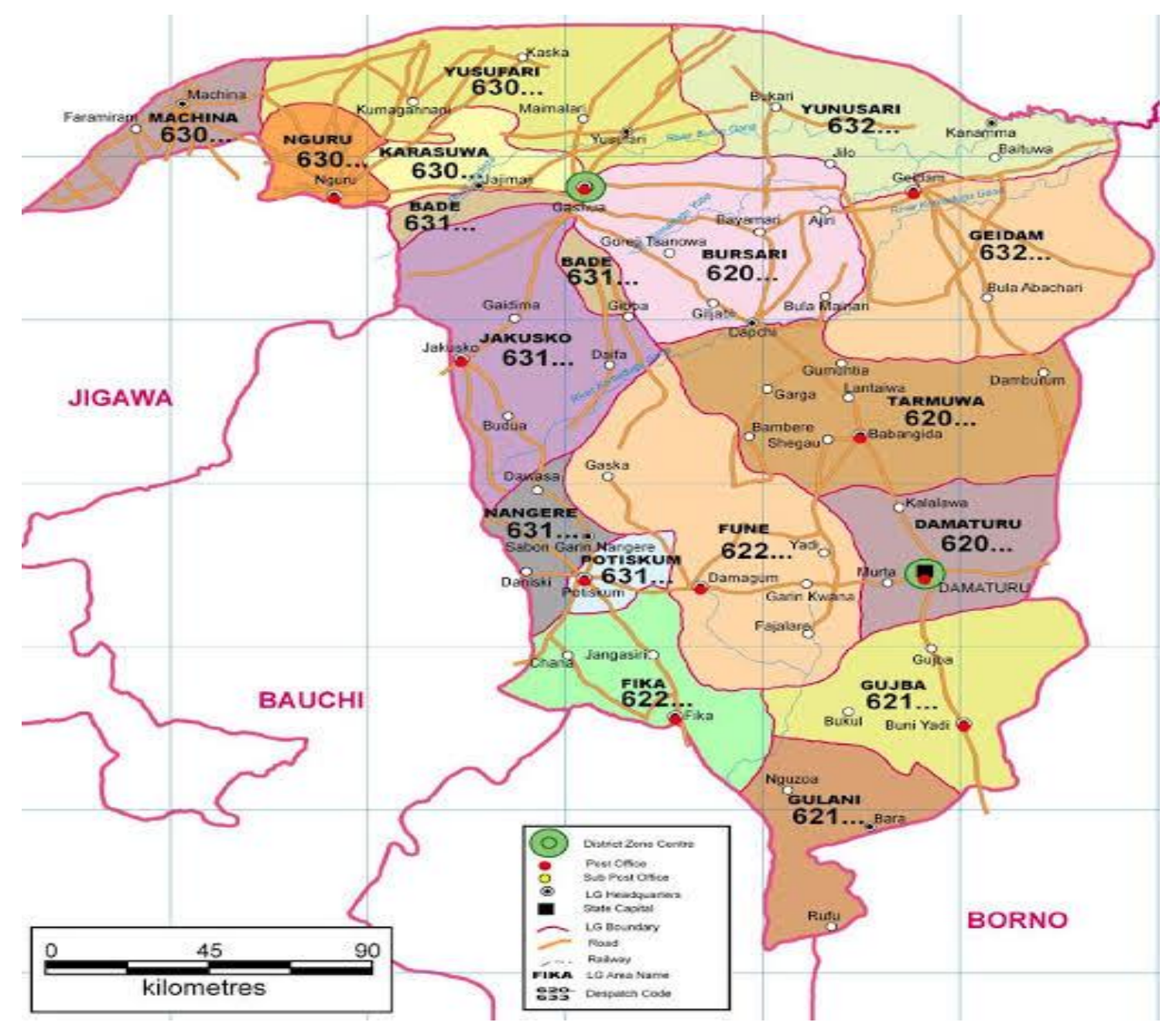

Figure 1: Map of Yobe State.

\section{Analysis}

\section{Sample Collection and Preparation}

Samples of Rice and Beans were collected after farm harvests at different local governments within each Senatorial Zone. Zonal composite samples were randomly chosen from different areas within each zone and were named according to the representative zone as ZAR, ZAB, ZBR, ZBB, ZCR and ZCB for Zone A Rice, Zone A Beans, Zone B Rice, Zone B Beans, Zone C Rice and Zone C Beans respectively. In all cases, the samples were collected in sterile sample bags and sealed before transporting to the laboratory. The samples were washed with de-ionized water and dried to constant weight in a hot air oven at $65^{\circ} \mathrm{C}$ for $20 \mathrm{hrs}$, ground to powder and stored in clean airtight containers.
Five $5.0 \mathrm{~g}$ of the prepared samples were air-dried, ground in an agate mortar, placed in quartz crucibles for dry ashing and mineralized thermally in a muffle furnace at $450{ }^{\circ} \mathrm{C}$ for $12 \mathrm{hrs}$. The mineralized samples were then acid digested by dissolving in $20 \mathrm{ml}$ of $1: 1(\mathrm{v} / \mathrm{v})$ concentrated $\mathrm{HNO}_{3}$ and $\mathrm{HCl}$ acids in a $100 \mathrm{ml}$ volumetric flask. The flask was then heated in an electrothermal heater with gentle swirling till digestion was completed by the evolution of white fumes. The cooled digests were filtered through Whatman No 1 filter paper into a $50 \mathrm{ml}$ volumetric flask and was diluted to the $50 \mathrm{ml}$ mark with de-ionized water. The heavy metals contents of the samples were determined using the Atomic Absorption Spectrophotometer (AAS) and calculated using the relation $y=m x+c$ from calibration of each metal standard (AOAC, 2003). 


\section{Determining Daily Intake of Metals (DIM) and Health Risk Index (HRI)}

The Daily Intake of Metals (DIM) was determined as described by Wang et al. (2005).

$\mathrm{DIM}=\mathrm{C}_{\text {Grains }} \times \mathrm{C}_{\text {Factor }} \times \mathrm{D}_{\text {Food Intake }} / \mathrm{B}_{\text {Average Body Weight }}$

Where: $\mathrm{C}_{\text {Grain }}=$ Concentration of heavy metals in grains $(\mathrm{mg} / \mathrm{Kg})$,

$$
\mathrm{C}_{\text {Factor }}=0.085 \text {, }
$$

$\mathrm{D}_{\text {Food Intake }}=0.345 \mathrm{~kg}$ per day for adults,

B Average Body Weight $=55.90 \mathrm{~kg}$ for adults (Wang et al., 2005).

Health Risk Index was calculated as described by US-EPA (2002).
$\mathrm{HRI}=\mathrm{DIM} / \mathrm{RFD}$

Where RFD $=$ Reference Oral Dose (US-EPA, 2002).

$$
\text { DIM = Daily Intake of Metals }
$$

\section{RESULT AND DISCUSSION}

\section{Results}

Table 1 shows the mean concentration of toxic metals in Rice and Beans across the three Senatorial Zones of Yobe State. Although there is a significant $(\mathrm{p}<0.05)$ difference between the concentration of heavy metals within the zones, all except mercury are within tolerable limits set by International Standard Tolerable Limits and European Regulatory Standard.

Table 1: Mean concentration of toxic metals in Rice and Beans samples of three Senatorial Zones of Yobe State, Nigeria

\begin{tabular}{lllll}
$\begin{array}{l}\text { Parameters } \\
\text { Sample }\end{array}$ & Mercury & Lead & Cadmium & Chromium \\
\cline { 1 - 4 } & & & & \\
\hline ZAR & $0.30 \pm 0.44^{\mathrm{b}}$ & $0.16 \pm 0.08^{\mathrm{a}}$ & $0.03 \pm 0.00^{\mathrm{a}}$ & $0.02 \pm 0.02^{\mathrm{a}}$ \\
ZAB & $0.14 \pm 0.20^{\mathrm{c}}$ & $0.05 \pm 0.10^{\mathrm{c}}$ & $0.00 \pm 0.00$ & $0.00 \pm 0.00$ \\
ZBR & $0.40 \pm 0.04^{\mathrm{a}}$ & $0.17 \pm 0.02^{\mathrm{b}}$ & $0.03 \pm 0.00^{\mathrm{a}}$ & $0.00 \pm 0.00^{\mathrm{b}}$ \\
ZBB & $2.04 \pm 1.30^{\mathrm{c}, \mathrm{d}}$ & $0.25 \pm 0.13^{\mathrm{c}, \mathrm{d}}$ & $0.03 \pm 0.00^{\mathrm{c}}$ & $0.02 \pm 0.02^{\mathrm{c}}$ \\
ZCR & $4.04 \pm 0.17^{\mathrm{a}, \mathrm{b}}$ & $0.91 \pm 0.02^{\mathrm{a}, \mathrm{b}}$ & $0.05 \pm 0.00^{\mathrm{a}, \mathrm{b}}$ & $0.05 \pm 0.00^{\mathrm{a}, \mathrm{b}}$ \\
ZCB & $3.73 \pm 0.15^{\mathrm{d}}$ & $0.33 \pm 0.06^{\mathrm{d}}$ & $0.07 \pm 0.01^{\mathrm{c}}$ & $0.14 \pm 0.00^{\mathrm{c}}$ \\
\hline
\end{tabular}

Values are expressed as mean \pm S.D. values bearing similar superscript in the same column are significantly $(\mathrm{p}<0.05)$ different compared to each other.

Key: $\mathrm{ZAR}=$ Zone A Rice, $\mathrm{ZAB}=$ Zone A Beans, $\mathrm{ZBR}=$ Zone $\mathrm{B}$ Rice, $\mathrm{ZBB}=$ Zone $\mathrm{B}$ Beans, $\mathrm{ZCR}=$ Zone $\mathrm{C}$ Rice and $\mathrm{ZCB}=$ Zone $\mathrm{C}$ Beans.

Table 2: Daily Intake of Toxic Metals in Rice and Beans across the Three Senatorial Zones under Study.

\begin{tabular}{llllllllc}
\hline Study & \multicolumn{2}{c}{ Hg } & \multicolumn{2}{c}{ Pb } & \multicolumn{2}{c}{ Cd } & \multicolumn{2}{c}{ Cr } \\
Area & Rice & Beans & Rice & Beans & Rice & Beans & Rice & Beans \\
\hline Zone A & $8.2 \times 10^{-4}$ & $6.4 \times 10^{-4}$ & $8.3 \times 10^{-5}$ & $1.0 \times 10^{-5}$ & $1.5 \times 10^{-5}$ & $1.5 \times 10^{-5}$ & 0 & 0 \\
Zone B & $8.8 \times 10^{-4}$ & $1.1 \times 10^{-3}$ & $8.3 \times 10^{-5}$ & $9.4 \times 10^{-5}$ & $1.5 \times 10^{-5}$ & $1.5 \times 10^{-5}$ & 0 & 0 \\
Zone C & $15.6 \times 10^{-3}$ & $12.7 \times 10^{-3}$ & $9.4 \times 10^{-5}$ & $1.2 \times 10^{-4}$ & $2.0 \times 10^{-5}$ & $2.0 \times 10^{-5}$ & $1.5 \times 10^{-5}$ & $1.2 \times 10^{-5}$ \\
\hline
\end{tabular}

Table 2 show the daily intake of toxic metals across the zones. From the results, rice and beans from Zone $\mathrm{C}$ provided the highest daily intake of Mercury. This was followed by Zone A and lastly Zone B.

148 This work is licensed under a Creative Commons Attribution 4.0 International License. 
The Health Risk Index of toxic metals across the zones was presented in Table 3. From the results, rice and beans from Zone $\mathrm{C}$ had the highest Health Risk Index due to high Mercury content, followed by Zone A and lastly Zone B. All the remaining toxic metals showed a Health Risk Index of less than one.

Table 3: Health Risk Index in Rice and Beans across Three Zones of Yobe State, Nigeria.

\begin{tabular}{llllllllc} 
Study area & Hg & \multicolumn{3}{c}{ Pb } & \multicolumn{2}{c}{ Cd } & Cr \\
& Rice & Beans & Rice & Beans & Rice & Beans & Rice & Beans \\
\hline Zone A & 2.7 & 2.1 & 0.023 & 0.003 & 0.015 & 0.015 & 0 & 0 \\
Zone B & 2.9 & 3.6 & 0.023 & 0.026 & 0.015 & 0.015 & 0 & 0 \\
Zone C & 7.3 & 7.3 & 0.028 & 0.035 & 0.02 & 0.02 & 0 & 0 \\
\hline
\end{tabular}

\section{Discussion}

The study evaluated the levels of toxic metals (Mercury, Lead, Cadmium and Chromium) in rice and beans across Yobe State. Mean $\mathrm{Pb}, \mathrm{Cd}$ and $\mathrm{Cr}$ concentration of the samples were within the respective limits of $150 \mathrm{mg} / \mathrm{Kg}, 3 \mathrm{mg} / \mathrm{Kg}$ and 100 $\mathrm{mg} / \mathrm{Kg}$ set by International Standard Tolerable Limits. However, samples from Zone $\mathrm{C}$ have mean Mercury $(\mathrm{Hg})$ concentration above $1 \mathrm{mg} / \mathrm{Kg}$, the limits set by International Standard Tolerable Limits.

The established levels of these toxic metals in the farm produce in Zone $\mathrm{C}$ could be alarming and may indicate their build-up to the food chain. It may, therefore, serve as means of exposing the human population to these toxic metals. This may be convinced by consideration of the outstanding characteristics of the elements "non-destroyable and bioaccumulating". The findings of the study established alarming concentration of $\mathrm{Hg}$ in most of the samples analysed, despite the non or less toxic effect due to exposure of low levels of metallic Mercury speculated by some researchers (Davidson, et al., 2004). Biotransformation of the inorganic $\mathrm{Hg}$ to organic $\mathrm{Hg}$ such as Methyl Mercury may occur, that potentiate the toxic effects of the Mercury which includes lung damage, nausea, vomiting, diarrhoea, increase in blood pressure or heart rate, skin rashes, eye irritation, permanently damage to brain, kidneys and developing foetuses (Martin, \& Griswold, 2009; Davidson, et al., 2004).

Alhassan et al. (2012) pointed out that human exposure to Lead can result in many biological effects depending on the level and duration of exposure. Lead resembles Calcium as a divalent ion, it is therefore handled by the body as if it were $\mathrm{Ca}$, hence replacing the Calcium in many biological systems and protein matrix with concomitant loss of biological activity. In addition, other biochemical toxicity of Lead could be associated with its affinity to cell membrane and mitochondria, where it interferes with oxidative phosphorylation It also interferes with $\mathrm{Na}, \mathrm{K}$ and $\mathrm{Ca}$ ATPase pumps (Schuhmacher, et al., 1991). Chronic Lead exposure to blood level $>1.4 \mu \mathrm{g} / 1$ in children is believed to cause mental retardation, selective deficits in language, cognitive function, balance, behavioural and school performance. Across all ages, chronic exposure to Lead is associated with kidney damage and interstitial nephritis, affect sperm and ova, anaemia, CNS defects, peripheral neuropathies and reduced birth weight. Susceptibility to Lead toxicity is governed by genetic factors as established in the Caucasian population with a $15 \%$ variant of gene code for Delta-Aminolevulinic Acid Dehydratase (ALAD), hence become more susceptible to Lead exposure (Pirzada et al., 2009).

Cadmium is a very toxic metal found in all soils, including coal and mineral fertilizers. Cadmium has many uses, including batteries, pigments, metal coatings, and plastics. It is used extensively in electroplating (Peter, 2005). Cadmium and Cadmium compounds are known human carcinogens. Smokers get exposed to significantly higher Cadmium levels than non-smokers. Severe damage to the lungs may occur through breathing high levels of Cadmium common to cigarette smokers. High levels of ingestion induce severe stomach irritation that induces vomiting and diarrhoea, while Long-term exposure to lower levels leads to a build-up in the kidneys and possible 
kidney disease, lung damage, and fragile bones (Somers, 1983).

Chromium is found in rocks, animals, plants, and soil. Its compounds bind to soil and are not likely to migrate to groundwater; they are very persistent in sediments in the water. Chromium is used in metal alloys such as stainless steel, protective coatings on metals (electroplating), magnetic tapes, pigments for paints, cement, paper, rubber, composition floor covering and other materials. Its soluble forms are used in wood preservatives (Lynch, \& Braithwaite, 2005). Chromium (VI) compounds are toxins and known human carcinogens, whereas Chromium (III) is an essential nutrient. Breathing high levels can cause irritation to the lining of the nose, nose ulcers, runny nose and breathing problems such as asthma, cough, shortness of breath or wheezing (Alabdula'aly \& Khan, 2009).

The level of Cadmium and Chromium in the rice and beans samples from all the zones are not considered a health hazard. However, chronic exposure to such low levels may lead to the toxicity and carcinogenic properties of Chromium, softening of bones and kidney failure (Akinola, Njoku, \& Ekeifo, 2008). It is worth noting that most of the above-mentioned signs and symptoms of heavy metals toxicity are very common clinical cases in Yobe State nowadays and may not be unconnected to the build-up of these toxic metals in foods and ultimately in human tissues.

\section{CONCLUSION}

The study established that with the exception of Mercury, all the evaluated heavy metals are within the permissible limits set by International Standard Tolerable Limits and European Regulatory Standard. However, it is imperative to note that chronic exposure to these heavy metals even at low concentrations should be avoided.

\section{ACKNOWLEDGEMENTS}

This research work was supported by a grant from Tertiary Education Trust Fund (TETFund) under the Institutional Based Research (IBR) Program.

\section{REFERENCES}

Akinola, M. O., Njoku, K. L., \& Ekeifo, B. E. (2008). Determination of lead, cadmium and chromium in the tissue of an economically important plant grown around a textile industry at Ibeshe, Ikorodu area of Lagos State, Nigeria. Advances in Environmental Biology, 25-31.

Alabdula'aly, A. I., \& Khan, M. A. (2009). Heavy metals in cooler waters in Riyadh, Saudi Arabia. Environmental monitoring and assessment, 157(1), 23-28.

Alhassan, A. J., Sule, M. S., Atiku, M. K., Wudil, A. M., Dangambo, M. A., Mashi, J. A., \& Ibrahim, N. A. (2012). Study of correlation between heavy metal concentration, street dust and level of traffic in major roads of Kano Metropolis, Nigeria. Nigerian Journal of Basic and Applied Sciences, 20(2), 161-168.

AOAC. (2005). Official methods of analysis (15 Ed.). Washington, DC: Association of Official Analytical Chemists. 11-14.

Carpenter, D. O. (2001). Effects of metals on the nervous system of humans and animals. International journal of occupational medicine and environmental health, 14(3), 209-218.

Davidson, P. W., Myers, G. J., \& Weiss, B. (2004). Mercury exposure and child development outcomes. Pediatrics, 113(Supplement 3), 10231029.

Gray, C. W., McLaren, R. G., \& Roberts, A. H. (2003). Atmospheric accessions of heavy metals to some New Zealand pastoral soils. Science of the Total Environment, 305(1-3), 105-115.

International Standard Tolerable Limits (2001). Maximum levels of heavy metals in soil and foods. ISBN 9780123970268

Lynch, E., \& Braithwaite, R. (2005). A review of the clinical and toxicological aspects of 'traditional'(herbal) medicines adulterated with heavy metals. Expert opinion on drug safety, 4(4), 769-778.

Madyiwa, S. (2007). Modelling lead and cadmium uptake by star grass under irrigation with

$150 \mid$ This work is licensed under a Creative Commons Attribution 4.0 International License. 
treated wastewater (Doctoral dissertation, University of Pretoria).

Martin, S., \& Griswold, W. (2009). Human health effects of heavy metals. Environmental Science and Technology briefs for citizens, 15, 1-6.

Peter, B. W. (2005). Municipal solid waste compositing: Potential effect of heavy metals in municipal solid waste composts on plants and environment. Boyce Thompson Institute for Plant Research at Cornell University, 1-5.

Pirzada, H., Ahmad, S. S., Rashid, A., \& Shah, T. (2009). Multivariate analysis of selected roadside plants (Dalbergia sissoo and Cannabis sativa) for lead pollution monitoring. Pakistan Journal of Botany, 41(4), 1729-1736.

Schuhmacher, M., Bosque, M. A., Domingo, J. L., \& Corbella, J. (1991). Dietary intake of lead and cadmium from foods in Tarragona Province, Spain. Bulletin of environmental contamination and toxicology, 46(2), 320-328.

Somers, E. (1974). The toxic potential of trace metals in foods. A review. Journal of Food Science, 39(2), 215-217.

USEPA, IRIS. (2002). United State, Environmental Protection Agency, Integrated Risk Information System. http://www.epa.gov/iris/subs. Accessed 25 February 2010.

Wang, S. T. (2005). Study on predicting effects of the soil polluted with heavy metals on vegetables and method of assessing quality of the soil in vegetable plot irrigated with a sewage-a case study on Baoding suburb. Agricultural University of Hebei, China, 1-43.

World Health Organization (WHO). (2020) Joint FAO/WHO Food Standards Programme. Codex Committee on Food Additives and Contaminants. Thirty-second session. Draft Maximum levels of lead. Prepared by Denmark pp 389.

151 This work is licensed under a Creative Commons Attribution 4.0 International License. 